\title{
Multiculturalism in current tourism: Can tourism and travelling help to improve tolerance and understanding?
}

\author{
Alena Josefová1 ${ }^{a}$, Jiří Štýrský ${ }^{1}$ \\ ${ }^{1}$ University of Hradec Kralove, Rokitanskeho 62, Hradec Kralove 3, 500 03, Czech Republic
}

\begin{abstract}
The article focuses on one of the most important issues of the beginning of the 21st century, which is unprecedented move of people. This political, sociological, geographical and psycho-linguistics phenomenon needs qualitatively new approaches in meeting races, cultures, religions, customs and habits. What are the possibilities of cohabitation of people in these new political, cultural and economic conditions? The way can be intercultural exchange characterised by mutual respect and the will to understand otherness and other values.
\end{abstract}

Keywords. Multiculturalism; tourism; travelling; interculturalism; tolerance.

\section{Tourism and Travelling}

A lot of research proves $[3,1]$ that multicultural society and changes happening in the global world significantly influence the way we orientate ourselves in the world, the way we communicate as well as the way we travel.

Tourism and travelling is a current phenomenon par excellence. As of October 2012, the number of tourists reached one billion! This trend is within our civilization inseparably linked to meetings and clashes of different cultures, customs, religions, in particular between Western, or Euro-American, civilization and other civilizations. As a leading Czech expert on Native American cultures M. Zeleny says: "It is a shame to helplessly witness continuous extermination of one civilization which can teach us, people who just dash somewhere into the future, a lot. However, we are deaf, relishing in our successes, incessantly growing quality of living, our greed and pride. We are unable to see spiritual values of Amazonian Indians, whose culture could show us another way than the way we are taking..." [8].

It is movement expressing a set of needs, including resting, getting to know something new, longing for a temporary change of environment and new intense experience. This is, however, only one kind of current social movement among many!

\footnotetext{
${ }^{a}$ Corresponding author: alena.josef@seznam.cz
} 
Tourism belongs to attractive fields of study at both secondary schools and universities. The job of a guide in the time of booming tourism requires theoretical and practical knowledge, language and psychological skills as well as orientation in geographical, cultural and historical context. It is also necessary to be able to sense all forms of differences and dissimilar values in meeting different cultures. The guide must be assertive. Intercultural communication and its kind is significant too, whether it be verbal or nonverbal. Model situations in tourism and the methodology of solving them, including the prevention of extraordinary situations, must also be taken into account [5].

Here introduce the paper, and put a nome $\neg$ nclature if necessary, in a box with the same font size as the rest of the paper. The paragraphs continue from here and are only separated by headings, subheadings, images and formulae. The section headings are arranged by numbers, bold and $10 \mathrm{pt}$. Here follows further instructions for authors.

\section{Contemporary multicultural world}

Current world witnesses massive movement of people out of conflict areas of Africa and the Near East into European countries. Although the early 2015 saw a sharp rise in migration, this phenomenon has been happening for a much longer period of time. The 1960s brought about a huge wave of migration as people were looking for jobs in highly industrialized countries like the Netherlands, Belgium, and Scandinavian countries. Migrants naturally targeted former colonial powers. France and Great Britain absorbed thousands of immigrants from African and Asian countries. Germany soaked up Turks and people from former Yugoslavia.

Immigrants came together with their cultures, customs, and moralities which naturally clashed on everyday basis with cultures, social and legal rules of the receiving society. A new problem came into being, namely whether the immigrants should adjust and dissolve in the majority or maintain their identity and sui generis uniqueness. It became necessary to solve this problem. There were two ways of solving it - assimilation (Scandinavia) and discrimination (Germany, Switzerland). In all cases it is a problem of cohabitation with political, social, economic, demographic and psychological dimensions. The dilemma lies in the rate of mutual tolerance. The above mentioned development gave rise to a problem of optimal approach to what has been since the 1960s in modern Europe called multiculturalism. It is an intellectual movement - as well as political one - aiming at finding a solution to cohabitation of groups having different cultures, religions, moralities, languages, and understandings of law [2]. German Chancellor and British Prime Minister have recently rather pessimistically admitted that their concept of multiculturalism has failed.

What next, then? We believe that superficial views of those who believe in multiculturalism as merging different cultures, or prevailing the majority culture accepted and adopted by minorities, are useless. The same, however, applies to limitless tolerance when the majority totally respects cultural differences of minorities as it hinders natural integration. It is logical to look for a compromise when minorities naturally take over the official language of the receiving country but at the same time it is respected that their children must be taught the basics of their first language. This leads to healthy bilingualism as a prerequisite to mutual enrichment of both the majority and minorities. European languages have borrowed a lot of Arab vocabulary during the Moorish presence in the Iberian Peninsula between the 8th and 15th centuries.

Another problem linked to mutual respect concerns job opportunities that should enable minorities to live in a dignified way in full respect of both labour law and customs of the majority. Religion is another sensitive issue. There is a strong Muslim minority in Europe. Muslims have a right to live their religious live if by doing so they do not affect 
cohabitation with other religious groups as well as secular state. An interesting example of solving this problem is a law about Islam which has recently been adopted in Austria. Another instance is a conference of Islamic representatives, which was held in Saudi Arabia on 23rd February 2015. The participants denounced Islamic terrorism and appealed for positive dialogue among Muslims.

Iranian Nobel Peace Laureate Shirin Ebadi maintains [7] that she disagrees with wearing veil in public and adds that all women - Iranian as well as foreign ones should have a right to choose what to wear. At the same time she disapproves of banning Muslim women from wearing veils in Western countries. Both these approaches are wrong. Islam and Islamic law are not mutually incompatible with the Western view of human liberty [7].

\section{Multiculturalism as a multi-problem}

The above mentioned cases show that it is impossible to exclude minorities and put them into ghettoes. On the other hand, segregation would be dangerous as people discriminated in this way are prone to listening to leaders who spread intolerance, religious hatred and fanaticism of all kinds.

With all that said, multiculturalism does not require only political solutions. It is a multi-problem related to linguistic issues as well as to travelling to non-European environment, where European travellers become a minority themselves and encounter other customs, religions, and historical memory. On the other hand, Western culture has a huge impact in non-European countries. Young people like European fashion and music, they use modern electronic devices. The main problem is how to combine varied traditions, wisdom based on long historical traditions and profound philosophies of, say, Buddhism with natural law to create a kind of civilised happiness, so nicely expressed by the King of Bhutan, who created for his country a system of values based of gross domestic happiness, instead of product. This may be the right way - or one of them.

In this respect, it is interesting to mention a sad reflection of the Czech traveller and photographer Zdenek Thoma, who during one of his visits to Nepal lived in a village shed and saw villagers watch one stupid film after another. He says that local viewers watch stories full of psychopaths, violent brawls, gun fights with a lot of casualties, fire explosions of inhabited houses. Or at least car chases and promiscuous relationships. The following morning they silently watch the foreigner as if asking: "Is this how you live in Europe and America?" [6].

\section{Mutual respect}

Cohabitation must have some optimal and constructive solution. It might be mutual respect and mutual acceptance. This mutual respect means that those who are kindly accepted pay back to the receiving society by accepting the position of debtors. Both sides must mutually accept cohabitation with those who are different. Such a plural society brings its members both profits and losses. Nevertheless, the majority can under no circumstances require any gratitude from the minority.

This type of cohabitation means a relatively harmonious living in case all basic principles of the majority are maintained and traditions of the minority are respected. The members of the minorities then much more easily get rid of their status of being foreigners and integrate into the society. This mutuality is however in total opposition to the current state when differences of minorities are disrespected and minorities themselves do not comply with reasonable principles of the majority. Integration may be successful only if it is accepted by the integrated. 
These reflections are an attempt to draw attention to the complexity of this problem and the need for philosophical, sociological, politological as well as psychological approaches. Travellers inevitably encounter these problems and tour guides may play an important role in influencing their clients as active promoters of mutual understanding and cohabitation. Tolerance is of paramount importance as tolerant people have their own beliefs and keep to their own principles but accept that other people have a right to have and follow their own beliefs and way of life. If that is the case, there is no space for xenophobia or racism.

In other words, it is a way from plurality to unity (PLURIBUS UNUM) is currently in direct contradiction to the tendency from plurality to fragmentation (PLURIBUS DISIUNCTIO)(Sartoti,2005). This tendency manifests itself in Catalunia, the Basque country, Scotland as well as Ukraine. Is there any solution? Historical experience and the concept of good society say that it is reasonable to strive for federalization in countries with various linguistic, religious and ethnical groups which struggle with economic inequality and have their own historical and political development. In this respect the concept of multiculturalism is linked to a certain structural disbalance, which may lead to a real or potential dissension.

\section{Conclusion}

The concept of multiculturalism seems to be outdated. It is possible to replace it with the concept of interculturalism or a dynamic politological-psychological concept of intercultural communication. The basic principle is intercultural exchange characterised by mutual respect and willingness to understand any differences and values. Tourism and travelling have a capacity to contribute to mutual tolerance and to the acceptance of diverse principles.

\section{References}

1. Josefova, A. The Cultural diversity as a phenomenon of the multicultural society. Procedia-Social and Behavioral Science,152, (2014).

2. Josefova, A. , Styrsky, J. K pojetí multikulturalismu pri vzdelavani odborniku v cestovnim ruchu. In Vedecky vyzkum a vyuka jazyku IV, Hradec Kralove: Gaudeaumus. [The Role of Multiculturalism in Educating Experts in Tourism], (2011).

3. Pikhart, M. New horizons of intercultural communication: applied linguistics approach. Procedia-Social and Behavioral Science. 152, 954-957. ISSN 1877-0428, (2014).

4. Sartori,G. Pluralismus, multikulturalismus a přistěhovalci: esej o multietnicke spolecnosti. Praha: Dokoran, s.43. [Pluralism, Multiculturalism and Foreigners], (2005).

5. Styrsky, J., Petera, J. Prace pruvodce v soucasnych podminkach rozvoje cestovniho ruchu. Hradec Kralove: Gaudeamus. [The Job of a Tour Guide in Current Tourism], (2015).

6. Thoma,Z . Turiste a mizejici svet. In Psychologie dnes, June 2007, 19. [Tourists and the Vanishing World], (2007).

7. Turecek, B. Labyrintem Iranu. Praha: Knizni klub. [Through the Labyrinth of Iran], (2013).

8. Zeleny, M. Staleti plynou a indiani se stale bouri. MF Dnes, 15th June 2009, 10. [Centuries Flow and Native Americans still Riot], (2009). 